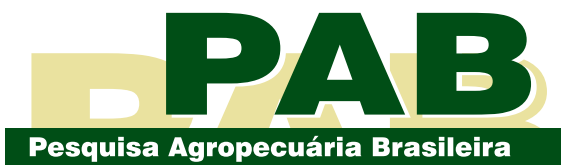

ISSN 1678-3921

Journal homepage: www.embrapa.br/pab

For manuscript submission and journal contents, access: www.scielo.br/pab
Fabrina Bolzan Martins ${ }^{(1 凶)(D),}$

Rodolfo Armando de Almeida Pereira(2) (D), Roger Rodrigues Torres ${ }^{(1)}$ (D) and

Diego Felipe dos Santos ${ }^{(3)}$ (D)

(1) Universidade Federal de Itajubá, Instituto de Recursos Naturais, Avenida BPS, № 1.303, Pinheirinho, CEP 37500-903 Itajubá, MG, Brazil

E-mail: fabrina@unifei.edu.br,

roger.torres@unifei.edu.br

(2) Universidade de São Paulo, Escola Superior de Agricultura Luiz de Queiroz, Pósgraduação em Engenharia de Sistemas Agrícolas, Avenida Pádua Dias, № 11, CEP 13418-900 Piracicaba, SP, Brazil. E-mail: rodolfopereira@usp.br

(3) Agrosmart, Avenida José Rocha Bonfim, no 214, Edifício Sidney, Sala 122, Center Santa Genebra, CEP 13080-650 Campinas, SP, Brazil.

E-mail: diego@agrosmart.com.br

$\bowtie$ Corresponding author

Received

March 10, 2020

Accepted

September 21, 2020

How to cite

MARTINS, F.B.; PEREIRA, R.A. de A.;

TORRES, R.R.; SANTOS, D.F. dos. Climate projections of chill hours and implications for olive cultivation in Minas Gerais, Brazil. Pesquisa Agropecuária Brasileira, v.55, e01852, 2020. DOI: https://doi.org/10.1590/ S1678-3921.pab2020.v55.01852.
Agrometeorology/ Original Article

\section{Climate projections of chill hours and implications for olive cultivation in Minas Gerais, Brazil}

\begin{abstract}
The objective of this work was to determine the accumulation of chill hours and to define the areas with aptitude for olive (Olea europaea) cultivation in the state of Minas Gerais, Brazil, as well as to analyze the impacts of climate change projections on chilling-hour requirements and climatic zoning, in two radiative forcing scenarios. The trigonometric method was used to quantify the number of chill hours, considering base temperatures $(\mathrm{Tb})$ of $7.0,9.5$, and $13^{\circ} \mathrm{C}$ (high, medium, and low chill, respectively), and was applied to present climate (1983-2012) and to two future climate (2041-2070 and 2071-2100) conditions. The present climate data were obtained from 47 conventional weather stations, and the future climate data were obtained from three Earth system models (IPSLCM5A-LR, MRI-CGCM3, and MIROC5). Future projections point to a decrease in the suitable areas for olive crop cultivation, particularly under representative concentration pathway (RCP) 8.5 and for olive cultivars with a high-chilling requirement $\left(\mathrm{Tb}=7.0^{\circ} \mathrm{C}\right)$. Of the olive cultivars requiring medium chill $\left(\mathrm{Tb}=9.5^{\circ} \mathrm{C}\right)$, only $2.6 \%$ (RCP 4.5 ) and $1.6 \%$ (RCP 8.5 ) will be suitable in the extreme south and in higher altitude areas of Minas Gerais, while, of those requiring low chill $\left(\mathrm{Tb}=13^{\circ} \mathrm{C}\right), 11.8 \%$ (RCP 4.5$)$ and $6.7 \%$ (RCP 8.5$)$ will be suitable. If the climate projections become true, the cultivation of olive crops will be viable in the southern region and in higher altitude areas of the state of Minas Gerais.
\end{abstract}

Index terms: Olea europaea, chilling-hour requirements, Earth system models, radiative forcing scenarios.

\section{Projeções climáticas de horas de frio e implicações na olivicultura em Minas Gerais, Brasil}

Resumo - O objetivo deste trabalho foi determinar o acúmulo de horas de frio e definir as áreas com aptidão para a olivicultura (Olea europaea) no estado de Minas Gerais, Brasil, assim como analisar os impactos das projeções de mudanças climáticas na exigência de horas de frio e no zoneamento climático, em dois cenários de forçantes radiativas. O método trigonométrico foi utilizado para quantificar o número de horas de frio, tendo-se considerado temperaturas basais $(\mathrm{Tb})$ de $7,0,9,5$ e $13^{\circ} \mathrm{C}$ (frio intenso, médio e suave, respectivamente), e foi aplicado para condições climáticas do presente (1983-2012) e para duas condições climáticas futuras (2041-2070 e 2071-2100). Os dados do clima presente foram obtidos de 47 estações meteorológicas convencionais, e os de clima futuro foram obtidos de três modelos do sistema terrestre (IPSL-CM5A-LR, MRI-CGCM3 e MIROC5). As projeções futuras apontam para uma diminuição das áreas aptas ao cultivo de oliveira, principalmente sob caminhos representativos de concentração (RCP) 8.5 e de cultivares com maior exigência em frio $\left(\mathrm{Tb}=7,0^{\circ} \mathrm{C}\right)$. Das cultivares de média exigência em frio $\left(\mathrm{Tb}=9,5^{\circ} \mathrm{C}\right)$, apenas $2,6 \%$ (RCP 4.5) e 1,6\% (RCP 8.5) serão aptas no extremo sul e nas áreas de maior altitude de Minas Gerais, enquanto, das de baixa exigência $\left(\mathrm{Tb}=13^{\circ} \mathrm{C}\right), 11,8 \%(\mathrm{RCP} 4.5)$ e $6,7 \%$ (RCP 8.5$)$ serão aptas. Se as condições climáticas se realizarem, o cultivo de oliveira será viável na região sul e em áreas de maior altitude no estado de Minas Gerais.

Termos para indexação: Olea europaea, exigência de horas de frio, modelos do sistema terrestre, cenários de forçantes radiativas. 


\section{Introduction}

Climate projections indicate considerable changes in the meteorological patterns in large part of Brazil throughout the twenty-first century, mainly related to increases in air temperature (IPCC, 2013; Santos et al., 2017b; Silva et al., 2019). These changes will affect mostly the regions of the country that depend on agribusiness, such as the state of Minas Gerais (Natividade et al., 2017; Martins et al., 2018).

The projected increases in air temperature might be harmful to agriculture in this state due to their direct influence on plant development and growth (Florêncio et al., 2019; Fraga et al., 2019). Plants sense absolute and gradual changes in temperature patterns through their thermosensing mechanism, which relays a signal to downstream components, altering metabolic composition, tissue type, and phenological stages, as briefly described by Bahuguna \& Jagadish (2015). In general, plants have thermal thresholds for a proper development and growth, being the two main ones: cold (chilling) and heat (forcing) requirements (Fraga et al., 2019). For instance, rising temperatures, as projected in future climate for the state of Minas Gerais (Santos et al., 2017b; Reboita et al., 2018) might alter the developmental rates (Florêncio et al., 2019), the phenological (i.e. timing of flowering and ripening), as well as physiological responses (Moriondo et al., 2015), consequently changing the areas currently suitable for certain crops.

Therefore, as shown in studies carried out recently in various locations around the world, one of the impacts of the projected global warming will be a drastic reduction in the areas suitable for cultivating several crops, such as corn (Zea mays L.) (RamirezCabral et al., 2017), cassava (Manihot esculenta Crantz) (Tironi et al., 2017), coffee (Coffea arabica L.) (Tavares et al., 2018), grape (Vitis vinifera L.) (Fraga et al., 2019), gladiola (Gladiolus $\times$ grandifloras Hort.) (Becker et al., 2021), and olive (Olea europaea L.) (Fraga et al., 2019, 2020b), as well as for growing certain forest species (Pirovani et al., 2018). However, temperate perennial fruits will be the most affected, because they largely depend on the availability and accumulation of the chill hours required by the plant (Moriondo et al., 2015; Ramos et al., 2018; Fraga et al., 2019). Chilling requirements refer to an extended accumulation of cold hours during the winter season, which enables a plant to leave the dormancy stage, properly setting buds and producing fruits when warmer temperatures arrive (Fraga et al., 2019).

Among the temperate perennial fruits cultivated in the state of Minas Gerais, olive stands out (Garcia et al., 2018), particularly its most planted cultivars: Arbequina, Alto D'ouro, Galega, MGS GRAP541, MGS GRAP561, MGS GRAP575, and Koroneiki (Silva et al., 2012; Souza \& Martins, 2014; Martins et al., 2019). For olive trees, chilling requirements are usually a strict criterion to break dormancy, which occurs by the beneficial action of winter chill, and must be sufficient to satisfy plant physiological demands (Moriondo et al., 2015; Garcia et al., 2018; Ramos et al., 2018; Fraga et al., 2019).

Several modelling approaches are currently used to quantify chilling requirements (Angelocci et al., 1979; Melo-Abreu et al., 2004; Santos et al., 2017a). In Brazil, one of the most applied is called chilling-hour requirements (CHRs), allowing to quantify the number of hours in a day in which air temperature remains below a base temperature (Tb). Both CHRs and Tbs vary substantially among species, cultivars, and varieties (Santos et al., 2017a). For olive trees, the $\mathrm{Tb}$ values of $7.0,9.5$, and $13^{\circ} \mathrm{C}$ are commonly adopted for cultivars with the highest, medium, and lowest chilling requirements, respectively (Garcia et al., 2018).

Quantifying dormancy requirements is important since their non-fulfillment slows or stops the development of a crop and can also cause physiological and phenological anomalies, which makes an area unsuitable for planting (Santos et al., 2017a; Ramos et al., 2018). Considering climate change projection, Santos et al. (2017b) found a significant reduction in the suitable areas for olive cultivation in the state of Minas Gerais. However, the authors based their study on the impact of climate changes on evapotranspiration patterns and water balance, disregarding chilling requirements.

Therefore, it is still necessary to know the chilling requirements of olive trees in Minas Gerais, as well as the impacts of climate changes on climatic zoning, taking into account CHRs, mainly due the rising temperature projected for the future climate of the state (Santos et al., 2017b; Reboita et al., 2018).

The objective of this work was to determine the accumulation of chill hours and to define the areas with aptitude for olive cultivation in the state of Minas Gerais, Brazil, as well as to analyze the impacts of climate change projections on chilling-hour 
requirements and climatic zoning, in two radiative forcing scenarios.

\section{Materials and Methods}

To quantify chill hours, present and future climates were considered. For the present climate (PR0), daily air temperature data from 47 conventional weather stations maintained by Instituto Nacional de Meteorologia in the state of Minas Gerais were used. These data included the following temperatures (in Celsius): maximum (TM), minimum (Tm), and measured at 9:00 p.m. - local time (T21). The climatological period considered was from 1983-2012, from May to September, which are the coldest months (Garcia et al., 2018), representing cold accumulation in Minas Gerais. As recommended by Santos et al. (2017a), years with more than 5\% of missing data from May to September were disregarded in the calculation of the CHR climatological average.

For the future climate, the ensemble mean of the climate simulations and projections of three Earth system models (ESMs) was used. The ESMs were: IPSL-CM5A-LR, MRI-CGCM3, and MIROC5, belonging to the Coupled Model Intercomparison Project Phase 5 (CMIP5) and part of the Fifth Assessment Report of the Intergovernmental Panel on Climate Change - IPCC AR5 (Taylor et al., 2012; IPCC, 2013; Santos et al., 2017b; Florêncio et al., 2019). The horizontal resolution of these models varies from 1.1 to 3.8 degrees of latitude/longitude, being $1.9 \times 3.8$ for IPSL-CM5A-LR, 1.1×1.1 for MRI-CGCM3, and $1.4 \times 1.4$ for MIROC5; for this study, the grid point closest to each of the 47 conventional weather stations used was extracted.

Following Santos et al. (2017b), the daily values of TM, Tm, and T21 simulated for the historical period (HP) from 1971-2000 and projected for two future periods, called near future (PR1 $=2041-2070)$ and far future (PR2 = 2071-2100), were used. All CMIP5 projections were produced using radiative forcing scenarios, known as representative concentration pathways (RCPs) (Moss et al., 2010). In this work, the RCPs used were 4.5 and 8.5, which correspond, respectively, to an approximate radiative forcing at the end of the twenty-first century of $4.5 \mathrm{~W} \mathrm{~m}^{-2}\left(\mathrm{CO}_{2}\right.$ equivalent $\approx 650 \mathrm{ppm})$ and $8.5 \mathrm{~W} \mathrm{~m}^{-2}\left(\mathrm{CO}_{2}\right.$ equivalent $\approx$ $1,370 \mathrm{ppm}$ ), relative to pre-industrial conditions (Moss et al., 2010).
To improve the performance of the results and to minimize the cumulative error in the CHR simulation and projections, it was necessary to make bias corrections to the daily values of TM, Tm, and T21 obtained with the three ESMs. For this, the methodology used by Lenderink et al. (2007) was applied. Firstly, the bias between the simulated data from the HP and the observed data from the PR0 was obtained. Then, the bias calculated for each variable of the following equation was subtracted from the daily data of the climate projections (PR1 and PR2) in both RCPs:

$\operatorname{BiasVar}_{\mathrm{i}}=\operatorname{Var}_{\mathrm{PHi}}-\operatorname{Var}_{\mathrm{PROi}}$

where BiasVar ${ }_{i}$ is the bias of variable Var (Tm, TM, and T21); and $\operatorname{Var}_{\mathrm{PHi}}$ and $\operatorname{Var}_{\mathrm{PROi}}$ are the climatological average of variable Var simulated for the HP and observed in the present period, respectively. All the variables were calculated separately for each month i, varying from May to September.

For the calculation of CHRs, the CHRa method proposed by Angelocci et al. (1979) was used, since it allows computing the CHR for any $\mathrm{Tb}$ threshold and using variables that are easy to measure and that are readily available at weather stations (Santos et al., 2017a). In the CHRa method, a series of line segments are used to fit the daily temperature curve, with seven possible scenarios for the daily accumulation of CHR, as described in the following equation:

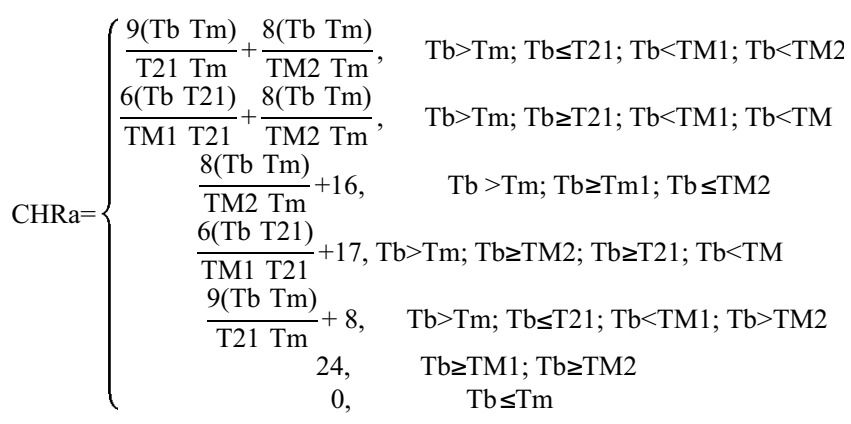

where CHRa is the number of chilling-hour requirements obtained by the method of Angelocci et al. (1979); Tb is the base temperature (7.0, 9.5, and $13^{\circ} \mathrm{C}$ ) for olive trees, i.e., the trigonometric approach; $\mathrm{Tm}$ is the minimum air temperature $\left({ }^{\circ} \mathrm{C}\right)$; TM1 is the maximum air temperature of the previous day $\left({ }^{\circ} \mathrm{C}\right)$; TM2 is the maximum air temperature of the current day $\left({ }^{\circ} \mathrm{C}\right)$; and T21 is the temperature measured at 9:00 
p.m. - local time. The values of Tm, TM, and T21 applied in these equations were obtained for the PR0, simulated for the HP and projected for PR1 and PR2, considering only May to September.

The daily CHR was accumulated to obtain annual values for the PR0, the HP, and both projections (PR1 and PR2) considering the two RCPs (4.5 and 8.5). Finally, the value of the average accumulated annual CHR was calculated for each of the 47 weather station points and each of the periods and RCPs analyzed.

To verify the impact of climate change on olive zoning based on CHRs, regions with CHR $\geq 300$ hours were considered suitable and those with CHR $<300$ hours, unsuitable (Melo-Abreu et al., 2004). The 300-hour threshold was chosen due to the wide variation between the methodologies for determining CHRs, cold requirements, and $\mathrm{Tb}$ values among olive cultivars (Melo-Abreu et al., 2004; Martins et al., 2019).

For the study, the main olive cultivars grown in the state of Minas Gerais were evaluated: Arbequina, Alto D'ouro, Galega, MGS GRAP541, MGS GRAP561, MGS GRAP575, and Koroneiki (Silva et al., 2012; Souza \& Martins, 2014; Martins et al., 2019). The MGS Mariense, Negroa, Cordovil de Serpa (Penafiel), MGS ASC315, MGS ASC 322, Arbosana, Ropades 392, and Santa Catalina cultivars, cultivated in the germplasm bank of Empresa de Pesquisa Agropecuária de Minas
Gerais, were also assessed due to their potential (Silva et al., 2012; Martins et al., 2019). All of these cultivars present different $\mathrm{Tb}$ values (Souza \& Martins, 2014; Martins et al., 2019), and, therefore, different CHRs.

To show the spatial pattern of the suitable/unsuitable classes, the obtained data were spatialized to a regular grid of $1^{\circ} \times 1^{\circ}$ latitude/longitude using the ordinary kriging interpolation method (Wickham, 2014) for the entire area of Minas Gerais.

\section{Results and Discussion}

The comparison between the Tm, TM, and T21 values obtained at the weather stations and simulated by the three ESMs (Figure 1) showed that T21 had the worst performance in the simulation, with an average overestimation of $2^{\circ} \mathrm{C}$, which justifies bias correction by the method of Lenderink et al. (2007), as previously described. The air-temperature values simulated by the models individually differed from the those observed for the state of Minas Gerais; however, the average values (ensemble mean) of the three models were close to those registered at the weather stations.

The mean spatial patterns of CHRs under current conditions, considering the PR0 and the HP, are shown in Figure $2 \mathrm{~A}-\mathrm{F}$. The CHR accumulation patterns were similar between the PR0 and the HP, with the

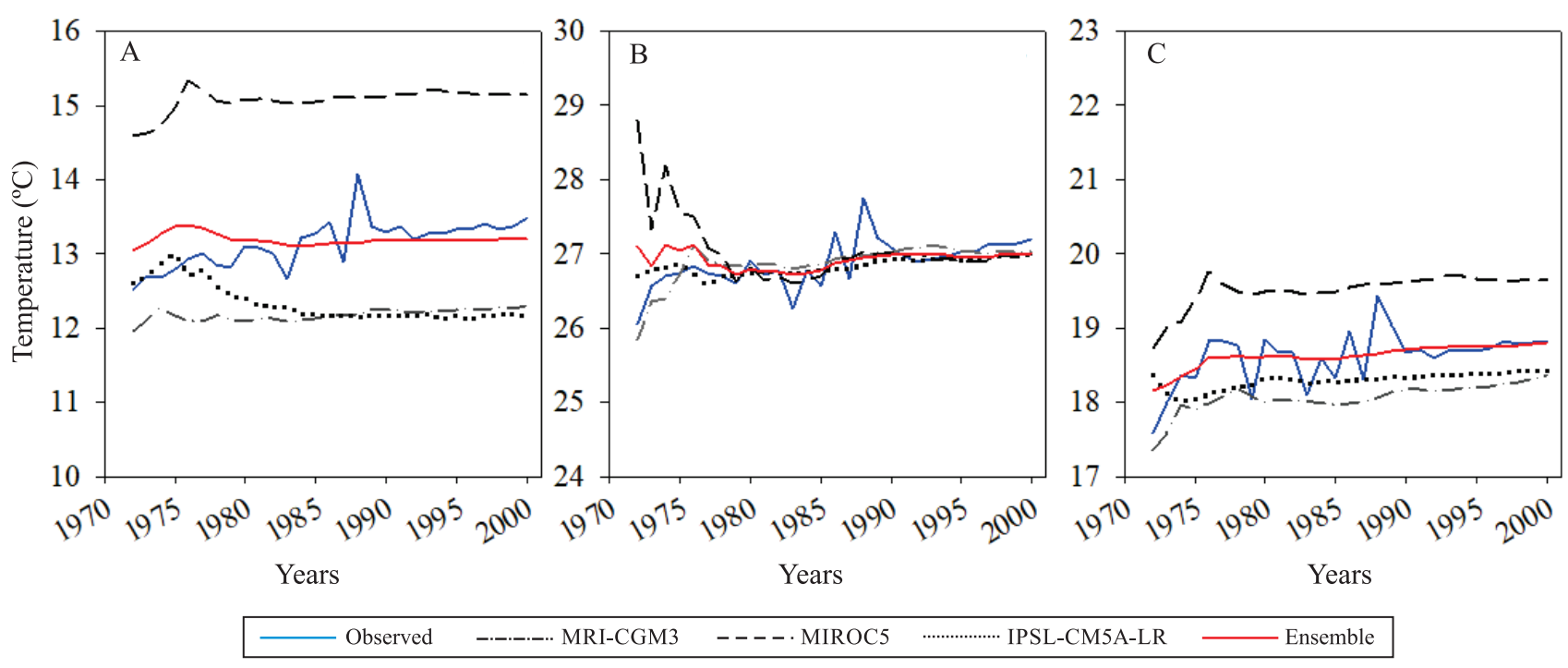

Figure 1. Time series for the following air temperatures: minimum (A), maximum (B), and measured at 9:0 p.m. - local time, obtained by three Earth system models (MRI-CGCM3, MIROC5, and IPSL-CM5A-LR) based on a historical simulation from 1971-2000 and on the data collected from 1983-2012 at conventional weather stations located in the state of Minas Gerais, Brazil. 
highest values in the south and center-south regions of Minas Gerais, mainly for $\mathrm{Tb}=13^{\circ} \mathrm{C}$ (Figure $2 \mathrm{C}$ and $\mathrm{F}$ ), and the lowest ones in the other regions of the state. The highest CHR values ( $>300$ hours) were observed only in regions of higher altitude, with a higher or lower magnitude, respectively, for $\mathrm{Tb}=9.5$ and $13^{\circ} \mathrm{C}$, decreasing progressively towards the north and northeast of the state, where the lowest values were found (CHR $\sim 0$ hour). These results are consistent with the climatology and the spatial pattern of minimum air temperature reported for Minas Gerais (Garcia et al., 2018).

Based on the climatic zoning in the PR0 and considering the total area of Minas Gerais $(586,528$ $\left.\mathrm{km}^{2}\right)$, only $1.1 \%\left(6.452 \mathrm{~km}^{2}\right)$ of the state was suitable for olive cultivation using the cultivars with the highest CHRs $\left(\mathrm{Tb}=7.0^{\circ} \mathrm{C}\right.$ ) (Table 1 and Figure $3 \mathrm{~A}$ ), such as: Alto D'ouro, Arbequina (Martins et al., 2019), and MGS Mariense (Souza \& Martins, 2014). This area is concentrated in the extreme south of Minas Gerais, a region with a higher altitude and a lower air temperature (Garcia et al., 2018). The cultivars with medium CHRs $\left(\mathrm{Tb}=9.5^{\circ} \mathrm{C}\right)$, such as Galega, MGS GRAP541, Negroa, and MGS ASC315, and those with the lowest $\mathrm{CHRs}\left(\mathrm{Tb}=13^{\circ} \mathrm{C}\right)$, including MGS GRAP561, MGS GRAP575, Cordovil de Serpa (Penafiel), Ropades 392, and Santa Catalina (Souza \& Martins, 2014; Martins et al., 2019), are suitable in approximately 4.0 and $39.3 \%$ of Minas Gerais, respectively (Table 1 and Figure $3 \mathrm{~B}$ and $\mathrm{C}$ ). For $\mathrm{Tb}=$ $9.5^{\circ} \mathrm{C}$, the suitable areas are concentrated in practically the entire southern region of the state, while, for $\mathrm{Tb}=$ $13^{\circ} \mathrm{C}$, the areas suitable for cultivars with a lower CHR are located, not only in this region, but in all southerncentral regions with an altitude above $1,000 \mathrm{~m}$.

The spatial patterns of CHRs in the future conditions (PR1 and PR2) under RCP 4.5 and 8.5 are shown in Figure $2 \mathrm{G}-\mathrm{R}$. Both of these scenarios depict a similar reduction in CHRs, with a higher intensity at the end of the twenty-first century under RCP 8.5, in agreement with some studies carried out in Minas Gerais (Natividade et al., 2017; Santos et al., 2017b; Reboita et al., 2018), indicating a gradual increase in air temperature. This increase can occur mainly in the western (called Triângulo Mineiro) and northwestern regions of the state, with a greater intensity in May $\left(\sim 3^{\circ} \mathrm{C}\right)$, September $\left(\sim 4.5^{\circ} \mathrm{C}\right)$, and October $\left(\sim 5^{\circ} \mathrm{C}\right)$ (Santos et al., 2017b), reducing the amount of chilling accumulation. In the southern and southern-central regions, which show aptitude for olive cultivation under current conditions (Figure 3), this projected increase can already vary from 3.0 to $4.5^{\circ} \mathrm{C}$ in all months of the year (Santos et al., 2017b; Reboita et al., 2018), even in the municipality of Maria da Fé $\left(\sim 4^{\circ} \mathrm{C}\right)$ (Florêncio et al., 2019), which is currently suitable for cultivars with the highest CHRs (Souza \& Martins, 2014). However, considering the projected spatial pattern, the maximum CHR values occur only in the extreme south of state and do not exceed 249 hours for $\mathrm{Tb}=7.0^{\circ} \mathrm{C}$ (Figure $2 \mathrm{G}$ ). The spatial pattern for $\mathrm{Tb}=9.5$ and $13^{\circ} \mathrm{C}$ is similar to that of $\mathrm{Tb}=7.0^{\circ} \mathrm{C}$, with differences in magnitude. For $\mathrm{Tb}$ $=9.5^{\circ} \mathrm{C}$, the values reach, approximately, 300 hours in the south and extreme south of state (Figure $2 \mathrm{H}, \mathrm{K}$, $\mathrm{N}$, and $\mathrm{Q}$ ), whereas, for $\mathrm{Tb}=13^{\circ} \mathrm{C}$, the greater $\mathrm{CHR}$ values also occur in the southern region ( $\sim 600$ hours); however, other regions with a higher altitude, such as the central part of the state, present CHR values above 450 hours at the end of twenty-first century under RCP 4.5 (Figure $2 \mathrm{I}$ and L). These results are indicative that there will be a decrease in the quantity and duration of chill hours, with a reduction in the suitable areas for olive cultivation (Table 1 and Figures 4 and 5).

Based on climate projections, the entire state of Minas Gerais will be unsuitable for the cultivation of cultivars with high-chilling requirements $\left(\mathrm{Tb}=7.0^{\circ} \mathrm{C}\right)$ in the near future in both forcing scenarios analyzed (Figure $4 \mathrm{~A}$ and $\mathrm{D}$ ). For the cultivars that require medium chilling $\left(\mathrm{Tb}=9.5^{\circ} \mathrm{C}\right)$, the suitable area might be drastically reduced to only $1.6 \%\left(9,384 \mathrm{~km}^{2}\right)$ in the far future under RCP 8.5 (Table 1), while, for lowchill requiring cultivars $\left(\mathrm{Tb}=13^{\circ} \mathrm{C}\right)$, the areas might be reduced to $6.7 \%\left(39.297 \mathrm{~km}^{2}\right)$ if the climate projections are confirmed (Figure $5 \mathrm{C}-\mathrm{F}$ and Table 1).

The climate projections for CHRs presented in this study indicate an insufficient chilling accumulation in the upcoming decades, especially for cultivars that require high chill. This means that Alto d'Ouro, Arbequina (Martins et al., 2019), and MGS Mariense (Souza \& Martins, 2014) should be avoided, while only the cultivars with the lowest CHRs, such as MGS GRAP561, MGS GRAP575, Cordovil de Serpa (Penafiel), Ropades 392, and Santa Catalina (Martins et al., 2019), should be cultivated, preferably in the southern and higher altitude regions of the state of Minas Gerais. Unfortunately, it is practically 

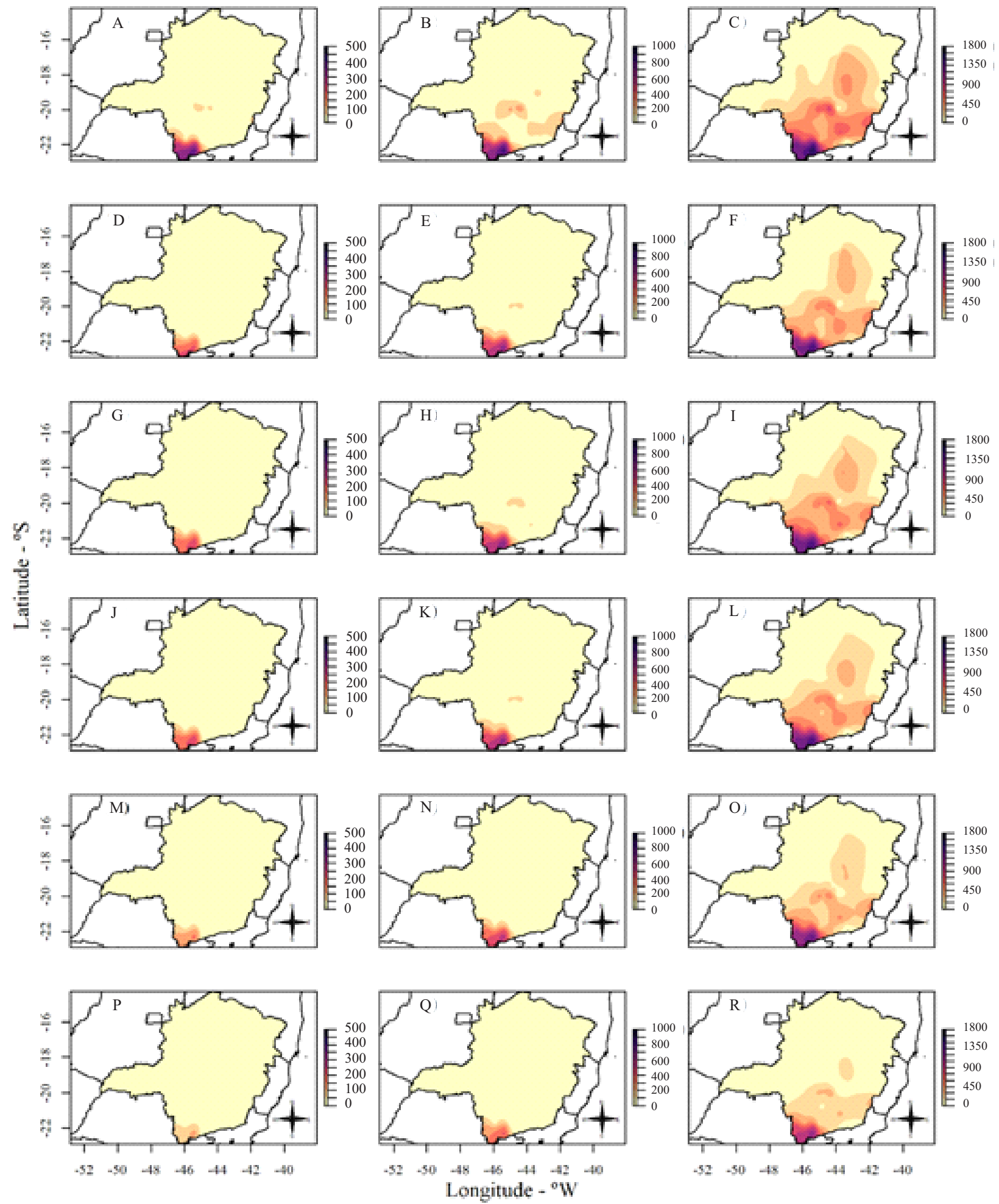

Figure 2. Chill hours accumulated in the state of Minas Gerais, Brazil, considering the base temperatures of 7.0, 9.5, and $13^{\circ} \mathrm{C}$, respectively, for the following scenarios: current conditions from 1983-2012 (A, B, and C), historical period (D, E, and F), future conditions for the near future from 2041-2070 (PR1) under representative concentration pathway (RCP) 4.5 (G, H, and I), PR1 under RCP 8.5 (J, K, and L), future conditions for the far future from 2071-2100 (PR2) under RCP 4.5 (M, N, and $\mathrm{O}$ ), and PR2 under RCP 8.5 (P, Q, and R). RCP 4.5 and 8.5 are the radiative forcing scenarios. 
impossible to confirm that other olive cultivars should be cultivated (or avoided) due the lack of studies of this nature, particularly regarding CHRs.

Therefore, there may be serious implications for the sustainability of olive cultivation in Minas Gerais, since chilling plays an important role in the flowering and fruit set of olive trees (García-Mozo et al., 2010; Fraga et al., 2019) and is also a major yield determinant (Ramos et al., 2018). Although olive trees exposed to insufficient chilling may indeed flower (Ramos et al., 2018), failure to receive sufficient chilling throughout seasons and years can lead to severe consequences (García-Mozo et al., 2010; Fraga et al., 2019) due to the resulting low fruit percentage (Ramos et al., 2018). Moreover, the lack of effective chilling during winter in a subtropical area, as that evaluated in the present study, also causes an extended and complex sequence of morphological, physiological, metabolic, and phenological changes (Guo et al., 2014; García-Mozo et al., 2010; Moriondo et al., 2015; Ramos et al., 2018).

Combined, these changes influence negatively the patterns and duration of the phenological phases of the olive crop (García-Mozo et al., 2010; Tanasijevic et al., 2014; Fraga et al., 2019). In addition, a series of phenological anomalies can also occur (Santos et al., 2017a; Ramos et al., 2018), which would lead to a progressive reduction in olive development, growth, productivity, and quality fruit production (Guo et al., 2014; Moriondo et al., 2015; Ramos et al., 2018). Possible changes in olive vegetative development include delays in the leaf appearance rate (Florêncio et al., 2019) and in vegetative bud break, and, in reproductive development, irregularities in budburst, flowering, and fruit ripening. Changes in the leaf appearance rate and in leaf opening will reduce the area intercepted by solar radiation, affecting the

Table 1. Proportion of suitable and unsuitable areas for olive (Olea europaea) crop cultivation in current and future conditions, considering two periods of climate projections and two radiative forcing scenarios (RCP 4.5 and 8.5 ) for three base temperatures (Tbs).

\begin{tabular}{|c|c|c|c|c|c|c|}
\hline \multirow[t]{2}{*}{ Condition/scenario ${ }^{(1)}$} & \multicolumn{2}{|c|}{ Suitable area $\mathrm{Tb}=7.0^{\circ} \mathrm{C}$} & \multicolumn{2}{|c|}{ Suitable area $\mathrm{Tb}=9.5^{\circ} \mathrm{C}$} & \multicolumn{2}{|c|}{ Suitable area $\mathrm{Tb}=13^{\circ} \mathrm{C}$} \\
\hline & $\%$ & $\mathrm{~km}^{2}$ & $\%$ & $\mathrm{~km}^{2}$ & $\%$ & $\mathrm{~km}^{2}$ \\
\hline PR0 & 1.1 & 6,452 & 4.0 & 23,461 & 39.3 & 23,0506 \\
\hline PR1 under RCP 4.5 & 0.0 & 0 & 2.6 & 15,250 & 34.6 & 202,939 \\
\hline PR1 under RCP 8.5 & 0.0 & 0 & 2.6 & 15,250 & 26.1 & 153,084 \\
\hline PR2 under RCP 4.5 & 0.0 & 0 & 2.6 & 15,250 & 11.8 & 69,210 \\
\hline PR2 under RCP 8.5 & 0.0 & 0 & 1.6 & 9,384 & 6.7 & 39,297 \\
\hline
\end{tabular}

(1)PR0, current conditions from 1983-2012; PR1, future conditions for the near future from 2041-2070; RCP, representative concentration pathway; and PR2, future conditions for the far future from 2071-2100.
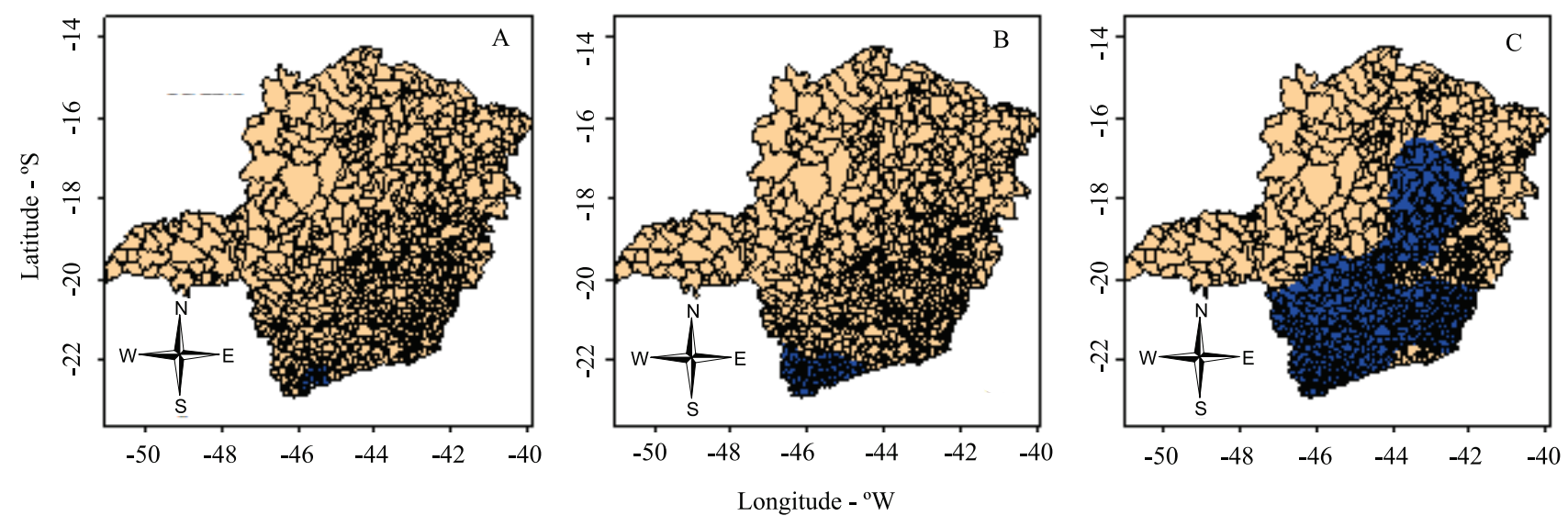

Figure 3. Agroclimatic zoning for the olive (Olea europaea) crop in the state of Minas Gerais, Brazil, considering current conditions from 1983-2012, based on the chill hours accumulated for the base temperatures of $7.0^{\circ} \mathrm{C}(\mathrm{A}), 9.5^{\circ} \mathrm{C}(\mathrm{B})$, and $13^{\circ} \mathrm{C}(\mathrm{C})$. 
photosynthetic rate, whereas vegetative break will extend the period of bud break (Moriondo et al., 2015; Garcia et al., 2018). However, greater changes are related to plant reproductive development (GarcíaMozo et al., 2010; Guo et al., 2014; Tanasijevic et al., 2014; Ramos et al., 2018), since bud and flower appearance occur only after the fulfilment of chilling requirements (Ramos et al., 2018). If insufficient chilling occurs, there will be delays in budding and flowering, an extended and/or uneven period of flowering, a reduction in budburst per branch, an increase in imperfect flowers, and, in more severe cases, floral abortion (Guo et al., 2014). This implies in a reduction in flower quality, the abscission of flower buds, the protraction of the flower process, and a reduction in the fruit set (García-Mozo et al., 2010; Guo et al., 2014; Tanasijevic et al., 2014; Ramos et al., 2018). All these factors will lead to small-sized fruits, reduced olive yield, and poor crop quality (Moriondo et al., 2015; Fraga et al., 2020b), besides affecting the longevity of the olive trees (Garcia et al., 2018).

In addition to reducing $\mathrm{CHRs}$, high temperatures $\left(>30^{\circ} \mathrm{C}\right)$ cause floral abortion at the beginning of flowering (García-Mozo et al., 2010; Tanasijevic et al., 2014) and affect stigma receptivity, ovule longevity, and pollen tube growth during pollination and flowering, impairing fertilization and fruit formation (Garcia et al., 2018).

For all these reasons, the projections depicted by the CMIP5 models will affect chill hours, reducing substantially the area suitable for olive cultivation in the state of Minas Gerais, mainly of cultivars with high-chilling requirements. This shows that the future impacts on the olive crop are also dependent on the cultivated cultivars or varieties (Fraga et al., 2019). Certain olive cultivars and varieties can be more
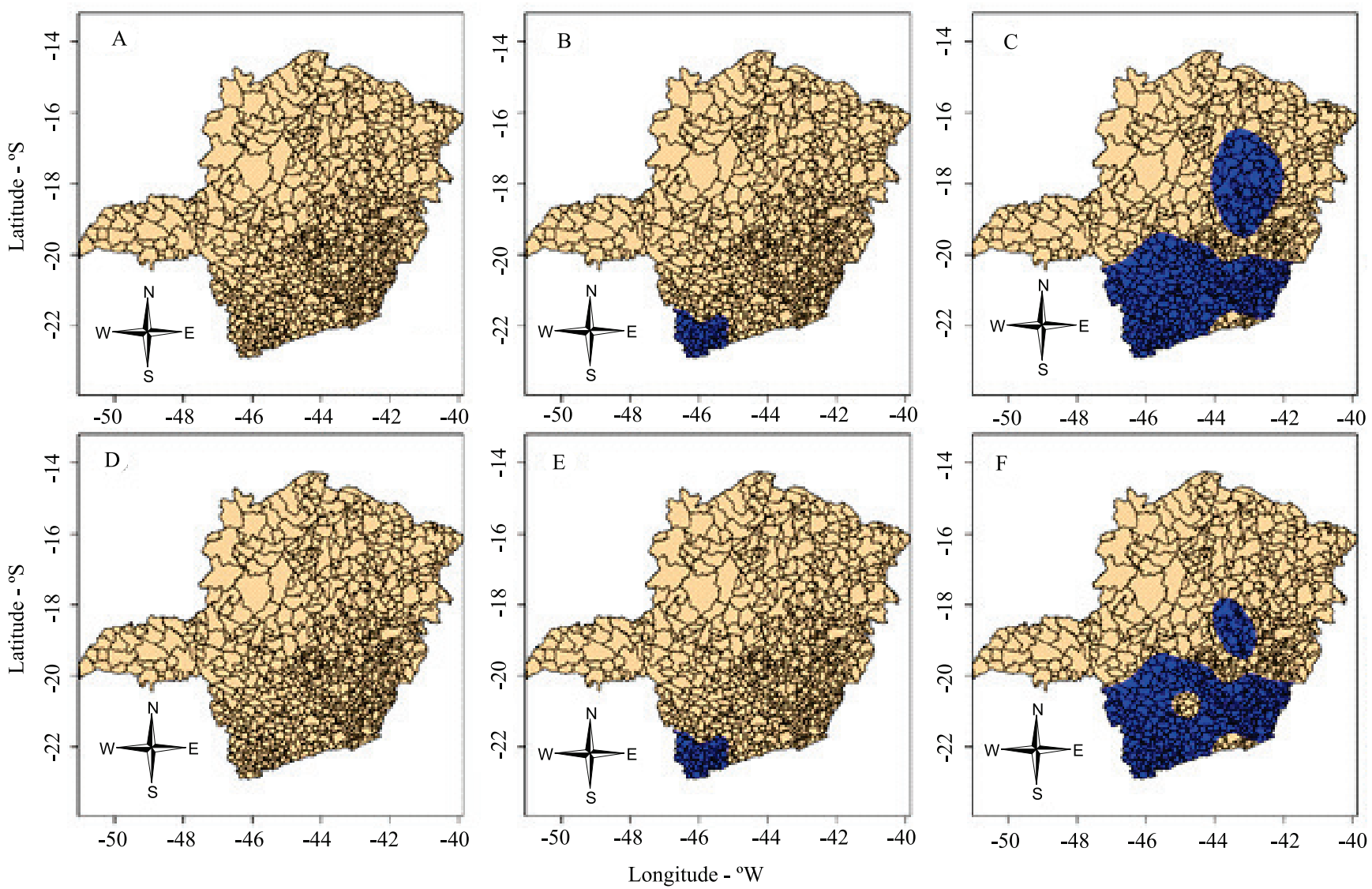

Figure 4. Zoning of the climatic aptitude of olive (Olea europaea) crops in the state of Minas Gerais, Brazil, considering the base temperatures of $7.0^{\circ} \mathrm{C}(\mathrm{A}$ and $\mathrm{D}), 9.5^{\circ} \mathrm{C}(\mathrm{B}$ and $\mathrm{E})$, and $13^{\circ} \mathrm{C}(\mathrm{C}$ and $\mathrm{F})$ in the radiative forcing scenarios $\mathrm{RCP} 4.5$ (A, B, and C) and RCP 8.5 (D, E, and F), in the near future from 2041-2070. RCP, representative concentration pathway. 

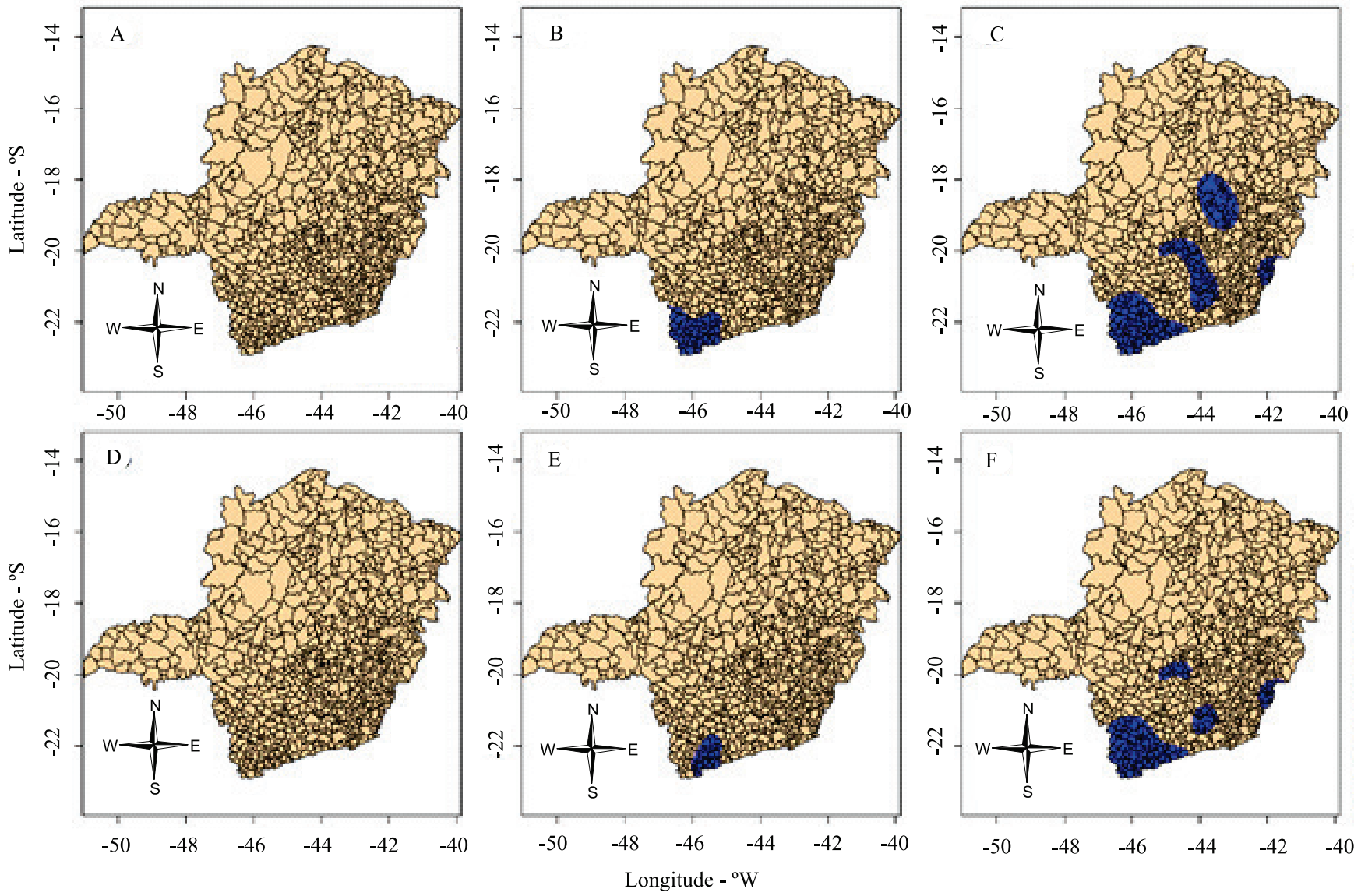

$\square$ Unsuitable $\quad \square$ Suitable

Figure 5. Zoning of the climatic aptitude of olive (Olea europaea) crops in the state of Minas Gerais, Brazil, considering the base temperatures of $7.0^{\circ} \mathrm{C}(\mathrm{A}$ and $\mathrm{D}), 9.5^{\circ} \mathrm{C}(\mathrm{B}$ and $\mathrm{E})$, and $13^{\circ} \mathrm{C}(\mathrm{C}$ and $\mathrm{F})$ in the radiative forcing scenarios $\mathrm{RCP} 4.5(\mathrm{~A}, \mathrm{~B}$, and C) and RCP 8.5 (D, E, and F), in the far future from 2071-2100. RCP, representative concentration pathway.

resilient to the negative impacts of changes under chill conditions, particularly regarding phenological timings (Melo-Abreu et al., 2004; Fraga et al., 2019). Therefore, it becomes crucial to develop and adopt suitable cultural practices aimed at specific climate threats. An example of a strategy used to adapt to future lower chilling is the development of practices to artificially break dormancy (Santos et al., 2017a; Garcia et al., 2018). Other cultural practices, such as the adoption of appropriate scion-rootstock combinations, may also reduce chilling requirements (Fraga et al., 2019).

Obviously, other adaptation measures can be adopted to alleviate the detrimental impacts of climate change on olive crops (García-Mozo et al., 2010; Tanasijevic et al., 2014; Fraga et al., 2020b). However, most of them, such as irrigation (Fraga et al., 2020a), are strictly dependent on water availability (Santos et al., 2017b), which may be problematic for some regions of the state of Minas Gerais (Santos et al., 2017b). Therefore, alternative or complementary strategies for adaptation to climate change should also be considered, including microclimate selection, varietal and clonal selection, soil management, cover crops, mulching, and fertilization (Fraga et al., 2019, 2020b).

\section{Conclusions}

1. There will be a significant decrease in the accumulation of the chill hours required by the olive (Olea europaea) crop in the entire state of 
Minas Gerais, Brazil, which will be intensified in the far future (2071-2100) and in the representative concentration pathway (RCP) 8.5 scenario of more intense greenhouse gas emissions.

2. Throughout the twenty-first century, the olive genotypes $\left(\mathrm{Tb}=7.0^{\circ} \mathrm{C}\right)$ with high-chilling requirements will be unsuitable for planting in the entire state of Minas Gerais, whereas the ones with medium-chilling requirements $\left(\mathrm{Tb}=9.5^{\circ} \mathrm{C}\right)$ will be suitable for planting only in $2.6 \%$ (RCP 4.5$)$ and $1.6 \%$ (RCP 8.5$)$ of the total area in the extreme south of the state, and those with low-chilling requirements $\left(\mathrm{Tb}=13^{\circ} \mathrm{C}\right)$ will be suitable for planting in $11.8 \%$ (RCP 4.5) and 6.7\% (RCP 8.5) of the total area.

3. By the end of twenty-first century (2071-2100) and under RCP 8.5, only the southern region of Minas Gerais will be suitable for the cultivation of the olive crop and of genotypes with low-chilling requirements.

\section{Acknowledgments}

To Fundação de Amparo à Pesquisa do Estado de Minas Gerais (Fapemig), for financial support (projects APQ-01392-13 and APQ 01258-17).

\section{References}

ANGELOCCI, L.R.; CAMARGO, M.B.P. de; PEDRO JR, M.J.; ORTOLANI, A.A.; ALFONSI, R.R. Estimativa do total de horas abaixo de determinada temperatura-base através das medidas diárias de temperatura do ar. Bragantia, v.38, p.27-36, 1979. DOI: https://doi.org/10.1590/S0006-87051979000100004.

BAHUGUNA, R.N.; JAGADISH, K.S.V. Temperature regulation of plant phenological development. Environmental and Experimental Botany, v.111, p.83-90, 2015. DOI: https://doi.org/10.1016/j.envexpbot.2014.10.007.

BECKER, C.C.; STRECK, N.A.; UHLMANN, L.O.; CERA, J.C.; FERRAZ, S.E.T.; SILVEIRA, W.B.; BALEST, D.S.; SILVA, L.F. da. Assessing climate change effects on gladiola in Southern Brazil. Scientia Agricola, v.78, e20180275, 2021. DOI: https://doi.org/10.1590/1678-992x-2018-0275.

FLORÊNCIO, G.W.L.; MARTINS, F.B.; FERREIRA, M. de C.; PEREIRA, R.A. de A. Impacts of climatic changes on the vegetative development of olive cultivars. Revista Brasileira de Engenharia Agrícola e Ambiental, v.23, p.641-647, 2019. DOI: https://doi.org/10.1590/1807-1929/agriambi.v23n9p641-647.

FRAGA, H.; PINTO, J.G.; SANTOS, J.A. Climate change projections for chilling and heat forcing conditions in European vineyards and olive orchards: a multi-model assessment. Climatic Change, v.152, p.179-193, 2019. DOI: https://doi.org/10.1007/ s10584-018-2337-5.
FRAGA, H.; PINTO, J.G.; SANTOS, J.A. Olive tree irrigation as a climate change adaption measure in Alantejo, Portugal. Agricultural Water Management, v.237, art.106193, 2020a. DOI: https://doi.org/10.1016/j.agwat.2020.106193.

FRAGA, H.; PINTO, J.G.; VIOLA, F.; SANTOS, J.A. Climate change projections for olive yields in the Mediterranean Basin. International Journal of Climatology, v.40, p.769-781, 2020 b. DOI: https://doi.org/10.1002/joc.6237.

GARCIA, S.R.; SANTOS, D.F. dos; MARTINS, F.B; TORRES, R.R. Aspectos climatológicos associados ao cultivo da oliveira (Olea europaea L.) em Minas Gerais. Revista Brasileira de Climatologia, v.22, p.188-209, 2018. DOI: https://doi.org/10.5380/ abclima.v22i0.56825.

GARCÍA-MOZO, H.; MESTRE, A.; GALÁN, C. Phenological trends in southern Spain: a response to climate change. Agricultural and Forest Meteorology, v.150, p.575-580, 2010. DOI: https://doi.org/10.1016/j.agrformet.2010.01.023.

GUO, L.; DAI, J.; RANJITKAR, S.; YU, H.; XU, J.; LUEDELING, E. Chilling and heat requirements for flowering in temperate fruit trees. International Journal of Biometeorology, v.58, p.11951206, 2014. DOI: https://doi.org/10.1007/s00484-013-0714-3.

IPCC. Intergovernamental Panel on Climate Change. Summary for policymakers. In: STOCKER, T.F.; QIN, D.; PLATTNER, G.K.; TIGNOR, M.M.B.; ALLEN, S.K.; BOSCHUNG, J.; NAUELS, A.; XIA, Y.; BEX, V.; MIDGLEY, P.M. (Ed.). Climate change 2013: the physical science basis. Contribution of Working Group I to the Fifth Assessment Report of the Intergovernmental Panel on Climate Change. Cambridge: Cambridge University Press, 2013. p.3-29.

LENDERINK, G.; BUISHAND, A.; VAN DEURSEN, W. Estimates of future discharges of the river Rhine using two scenario methodologies: direct versus delta approach. Hydrology \& Earth System Sciences, v.11, p.1145-1159, 2007. DOI: https://doi.org/10.5194/hess-11-1145-2007.

MARTINS, F.B.; FERREIRA, M. de C.; SILVA, L.F. de O. da; RAMALHO, V.R.M.; GONÇALVES, E.D. Temperatura do ar no desenvolvimento reprodutivo de cultivares de oliveira. Revista Brasileira de Meteorologia, v.34, p.179-190, 2019. DOI: https://doi.org/10.1590/0102-77863340022.

MARTINS, F.B.; GONZAGA, G.; SANTOS, D.F. dos; REBOITA, M.S. Classificação climática de Köppen e de Thornthwaite para Minas Gerais: cenário atual e projeções futuras. Revista Brasileira de Climatologia, Edição Especial Dossiê Climatologia de Minas Gerais, p.129-156, 2018. DOI: https://doi.org/10.5380/ abclima.v1i0.60896.

MELO-ABREU, J.P. de; BARRANCO, D.; CORDEIRO, A.M.; TOUS, J.; ROGADO, B.M.; VILLALOBOS, F.J. Modelling olive flowering date using chilling for dormancy release and thermal time. Agricultural and Forest Meteorology, v.125, p.117-127, 2004. DOI: https://doi.org/10.1016/j.agrformet.2004.02.009.

MORIONDO, M.; FERRISE, R.; TROMBI, G.; BRILLI, L.; DIBARI, C.; BINDI, M. Modelling olive trees and grapevines in a changing climate. Environmental Modelling \& Software, v.72, p.387-401, 2015. DOI: https://doi.org/10.1016/j. envsoft.2014.12.016. 
MOSS, R.H.; EDMONDS, J.A.; HIBBARD, K.A.; MANNING, M.R.; ROSE, S.K.; VAN VUUREN, D.P.; CARTER, T.R.; EMORI, S.; KAINUMA, M.; KRAM, T; MEEHL, G.A.; MITCHELL, J.F.B.; NAKICENOVIC, N.; RIAHI, K.; SMITH, S.J.; STOUFFER, R.J.; THOMSON, A.M.; WEYANT, J.P.; WILBANKS, T.J. The next generation of scenarios for climate change research and assessment. Nature, v.463, p.747-756, 2010. DOI: https://doi.org/10.1038/nature08823.

NATIVIDADE, U.A.; GARCIA, S.R.; TORRES, R.R. Tendência dos índices de extremos climáticos observados e projetados no estado de Minas Gerais. Revista Brasileira de Meteorologia, v.32, p.600-614, 2017. DOI: https://doi.org/10.1590/01027786324008 .

PIROVANI, D.B.; PEZZOPANE, J.E.M; XAVIER, A.C.; PEZZOPANE, J.R.M.; JESUS JÚNIOR, W.C. de; MACHUCA, M.A.H.; SANTOS, G.M.A.D.A dos; SILVA, S.F. da; ALMEIDA, S.L.H. de; PELUZIO, T.M. de O.; EUGENIO, F.C.; MOREIRA, T.R.; ALEXANDRE, R.S.; SANTOS, A.R. dos. Climate change impacts on the aptitude area of forest species. Ecological Indicators, v.95, p.405-416, 2018. DOI: https://doi.org/10.1016/j. ecolind.2018.08.002.

RAMIREZ-CABRAL, N.Y.Z.; KUMAR, L.; SHABANI, F. Global alterations in areas of suitability for maize production from climate change and using a mechanistic species distribution model (CLIMEX). Scientific Reports, v.7, art.5910, 2017. DOI: https://doi.org/10.1038/s41598-017-05804-0.

RAMOS, A.; RAPOPORT, H.F.; CABELLO, D.; RALLO, L. Chilling accumulation, dormancy release temperature, and the role of leaves in olive reproductive budburst: evaluation using shoot explants. Scientia Horticulturae, v.231, p.241-252, 2018. DOI: https://doi.org/10.1016/j.scienta.2017.11.003.

REBOITA, M.S.; MARRAFON, V.H. de A.; LLOPART, M.; ROCHA, R.P. da. Cenários de mudanças climáticas projetados para o estado de Minas Gerais. Revista Brasileira de Climatologia, Edição Especial Dossiê Climatologia de Minas Gerais, p.110-128, 2018. DOI: https://doi.org/10.5380/abclima.vli0.60524.

SANTOS, D.F. dos; LEITE, R.R.M.; MARTINS, F.B. Avaliação dos métodos de estimativa de número de horas frio para o sul e sudoeste do Paraná. Revista Brasileira de Climatologia, v.21, p.401-416, 2017a. DOI: https://doi.org/10.5380/abclima. v21i0.52382.
SANTOS, D.F. dos; MARTINS, F.B.; TORRES, R.R. Impacts of climate projections on water balance and implications on olive crop in Minas Gerais. Revista Brasileira de Engenharia Agrícola e Ambiental, v.21, p.77-82, 2017b. DOI: https://doi.org/10.1590/1807-1929/agriambi.v21n2p77-82.

SILVA, J.M.C. da; RAPINI, A.; BARBOSA, L.C.F.; TORRES, R.R. Extinction risk of narrowly distributed species of seed plants in Brazil due to habitat loss and climate change. PeerJ, v.7, e7333, 2019. DOI: https://doi.org/10.7717/peerj.7333.

SILVA, L.F. de O. da; OLIVEIRA, A.F. de; PIO, R.; ZAMBON, C.R. Caracterização agronômica e carpométrica de cultivares de oliveira. Pesquisa Agropecuária Tropical, v.42, p.350-356, 2012. DOI: https://doi.org/10.1590/S1983-40632012000300012.

SOUZA, P.M.B. de; MARTINS, F.B. Estimativa da temperatura basal inferior para as cultivares de oliveira Grappolo e Maria da Fé. Revista Brasileira de Meteorologia, v.29, p.307-313, 2014. DOI: https://doi.org/10.1590/S0102-77862014000200013.

TANASIJEVIC, L.; TODOROVIC, M.; PEREIRA, L.S.; PIZZIGALLI, C.; LIONELLO, P. Impacts of climate change on olive crop evapotranspiration and irrigation requirements in the Mediterranean region. Agricultural Water Management, v.144, p.54-68, 2014. DOI: https://doi.org/10.1016/j.agwat.2014.05.019.

TAVARES, P. da S.; GIAROLLA, A.; CHOU, S.C.; SILVA, A.J. de P.; LYRA, A. de A. Climate change impact on the potential yield of Arabica coffee in southeast Brazil. Regional Environmental Change, v.18, p.873-883, 2018. DOI: https://doi.org/10.1007/ s10113-017-1236-Z.

TAYLOR, K.E.; STOUFFER, R.J.; MEEHL, G.A. An overview of CMIP5 and the experiment design. Bulletin of the American Meteorological Society, v.93, p.485-498, 2012. DOI: https://doi.org/10.1175/BAMS-D-11-00094.1.

TIRONI, L.F.; STRECK, N.A.; SANTOS, A.T.L.; FREITAS, C.P. de O. de; UHLMANN, L.O.; OLIVEIRA JÚNIOR, W.C. de; FERRAZ, S.E.T. Estimating cassava yield in future IPCC climate scenarios for the Rio Grande do Sul State, Brazil. Ciência Rural, v.47, e20160315, 2017. DOI: https://doi.org/10.1590/01038478 cr20160315.

WICKHAM, H. Advanced R. Boca Raton: CRC Press, 2014. $476 \mathrm{p}$. 